\title{
Development of a discrete locating model for the healthcare facilities considering efficiency and readiness
}

Mohammadreza Alikhasi

operator of central control room at sepahan cement company - Esfahan -Iran

Mr.alikhasi@gmail.com

Mohammadreza Vasili

Assistant Professor, Department of Industrial Engineering, Islamic Azad University vasili@iauln.ac.ir

Editor Científico: José Edson Lara

Organização Comitê Científico

Double Blind Review pelo SEER/OJS

Recebido em 17.07.2019

Aprovado em 25.03.2020

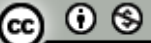

Este trabalho foi licenciado com uma Licença Creative Commons - Atribuição - Não Comercial 3.0 Brasil 


\begin{abstract}
The locating of facilities is one of the main issues in the field of operation research, and has always been a concern for many societies due to the very important role in controlling costs, quality and access to commodity and services. The use of modern scientific tools for locating in developed countries is very common and is considered as a solution to avoid mistakes in the organization of services and production. In developing countries, these tools are also very effective in improving the ability of communities. The result of the application of modern science in locating, anywhere around the world, is well established in the quality of service and the satisfaction of suppliers and applicants. In the implementation of locating, the demand of individuals in the communities is considered as dynamic and static. In the static facilities area due to the high relative dimensions and, in principle, the impossibility of low cost relocation, locating decisions assign high importance and precision. Given influence of the efficiency and readiness of a healthcare center such as a hospital in choosing new services and locations for establishing or maintaining a service, can be very helpful and will prevent future mistakes and adjust previous preferences. The most important question that has been answered in this study is the impact of the effectioncy and services in locating and allocating services and reexamining hospital capacities. By measuring the efficiency and readiness indexes through data envelopment analysis models and ranking the provided services, a more precise decision can be made and a review of the applied policies can be considered. Therefore, in this paper, a model is proposed with consideration of different services for a hospital and quality for each service, in which it seeks to minimize operational and maintenance costs and, as well as, maximize the quality and efficiency. The goal of this model is to provide an approach for optimal location of the centers, which reduces investment and operational costs. The proposed model is solved by the modified Epsilon Limit Approach. The results indicate the proper functioning of the system after the implementation of the proposed model.
\end{abstract}

KeyWords: Facilities locating - Healthcare facilities - Efficiency - Readiness - Data Envelopment Analysis

\title{
Desenvolvimento de um modelo de localização discreta para as unidades de saúde, considerando eficiência e prontidão
}

\section{Resumo}

A localização de instalações é uma das principais questões no campo da pesquisa operacional e sempre foi uma preocupação para muitas sociedades, devido ao papel muito importante no controle de custos, qualidade e acesso a mercadorias e serviços. O uso de ferramentas científicas modernas para localização em países desenvolvidos é muito comum e é considerado uma solução para evitar erros na organização de serviços e produção. Nos países em desenvolvimento, essas ferramentas também são muito eficazes para melhorar a capacidade das comunidades. O resultado da aplicação da ciência moderna na localização, em qualquer lugar do mundo, está bem estabelecido na qualidade do serviço e na satisfação de fornecedores e candidatos. $\mathrm{Na}$ implementação da localização, a demanda de indivíduos nas comunidades é considerada dinâmica e estática. $\mathrm{Na}$ área de instalações estáticas, devido às altas dimensões relativas e, em princípio, à impossibilidade de realocação de baixo custo, as decisões de localização atribuem alta importância e precisão. Dada a influência da eficiência e prontidão de um centro de saúde, como um hospital, na escolha de novos serviços e locais para estabelecer 
ou manter um serviço, pode ser muito útil e evitará erros futuros e ajustará as preferências anteriores. A questão mais importante que foi respondida neste estudo é o impacto da efetividade e dos serviços na localização e alocação de serviços e no reexame das capacidades hospitalares. Medindo os índices de eficiência e prontidão por meio de modelos de análise de envelope de dados e classificando os serviços prestados, uma decisão mais precisa pode ser tomada e uma revisão das políticas aplicadas. Portanto, neste artigo, é proposto um modelo considerando os diferentes serviços de um hospital e a qualidade de cada serviço, no qual ele busca minimizar os custos operacionais e de manutenção e, além de maximizar a qualidade e a eficiência. $\mathrm{O}$ objetivo deste modelo é fornecer uma abordagem para a localização ideal dos centros, o que reduz custos de investimento e operacionais. O modelo proposto é resolvido pela abordagem do limite de Epsilon modificada. Os resultados indicam o bom funcionamento do sistema após a implementação do modelo proposto.

Palavras-chave: Localização de instalações; Instalações de saúde; Eficiência; Prontidão; Análise do envoltória de dados

\section{Introduction}

Facility location has always been a challenging and important issue in many areas. In the industrial sector, locating is a form of cost reduction and the largest coverage and issues (Lee et al., 2018). Healthcare centers are one of the most important urban areas that directly contribute to the health of the individual and the community (Zhao et al., 2019). Simple accessibility to these centers is very important in every community, especially in urban communities (Tajbakhsh et al., 2019). The generalization of this concept to health and healthcare is the key to solving many of the involved problems such as the lack of access or poor access to healthcare applicants, the high cost of establishing in unnecessary places, and often associated human health issues (Akihal, 2006). Along with the locating a health facilities, one of the considered points by healthcare managers and healthcare providers, is to examine the efficiency indexes of this section, the results include mortality rates, hospitalization rates, rates of using a facility such as CT scans and etc. with its own high costs.

These indexes can help health decision makers to best deal with the lack of human and financial resources (Alti, 2006). To influence the efficiency and readiness of a healthcare center such as a hospital in choosing services and new places for establishing or maintaining a service can be very helpful. The most important question that has been answered in this research is the impact of the efficiency and quality of services in locating and allocating services and re-examining hospital capacities. By measuring the efficiency and readiness indexes through data envelopment analysis models and ranking the quality of the provided services, a more precise decision can be made and a review of the applied policies can be considered (Nejati et al. , 
2017). Efficiency means the degree to which objectives are achieved. In other words, it shows how well the results of the work have been fulfiled. This term has a great deal in defining and measuring productivity (Hung et al., 2015). Emergency preparedness issues can be involved as a technical problem that is relevant to transportation. In particular, the response time for access to the patient is an important issue for locating and relocating facilities. In many countries, emergency preparedness and accountability aspects have been combined with locating issues. This result is due to the fact that the transport of ordinary patients and emergency patients is performed by the same fleet (Nagurney et al., 2016). The presence of healthcare places necessarily means accessability and ability to use them. Locating of healthcare centers, regardless of issues such as the efficiency and accountability of facilities and human resources, can not be considered as a complete process, and the deficiencies in the future will appear in a various forms, such as dissatisfied patient and physician, wasting time of patient, and etc. In fact, the main subject that has been addressed is the question of whether it is necessary to plan to locate a place with the least time to access or not, although the healthcare centers in one area are never capable of serving and responding by the 100 percent readiness or the most coverage in the present form. Considering the importance of this issue in this research, along with the discussion of the locating of healthcare centers, the efficiency of facilitation are interested. It is attempted to present a mathematical programming model to discuss the efficiency and quality of service in the hospital, the level of preparedness and accountability.

The rest of this paper is structured as follows. Section 2 introduces the literature review. Section 3 provides mathematical modeling, section 4 addresses the methodology. Section 5 includes a numerical example, and Section 6 presents a case study. Finally, section 7 concludes.

\section{Literature review}

Many research has been done on the locating of the healthcare centers. Some of these studies are briefly summarized in this section:

Murali et al. (2012) studied the case of severe biological terrorist attacks, the city's main centers need to effectively distribute a lot of drugs. In this paper, the authors seek to locate these points. The type of problem is the maximum coverage, which is modeled by loss function and chance constraint associated with demand uncertainty. This model has been solved with a locationallocation metaheuristic algorithm. The intended case study for this model, diffusion of black hole disease in Los Angeles. Sharif et al. (2012) developed an allocation-location model for 
planning healthcare facilities in Malaysia. The base model used in their research is a maximum coverage model in which capacity constraints are also contemplated. The solution method presented in the paper was based on the genetic algorithm.

Vay et al. (2012), provided a model based on the maximum coverage for locating of shelters. In other words, their work combines the coverage of the collections and the maximum coverage. Yen et al. (2012) considered the problem of the maximum modular coverage of the optimal locating of emergency vehicles. The advantage of their investigation, compared with other investigations, is that not only considered capacity for the facility, but also includes different levels of it. Using GIS is another tip of their article. An application has been reviewed in 10 districts of the state of Georgia. The proposed model is solved by CPLEX.

Berman et al. (2013) investigated the problem of locating for transit-based evacuation under the risk of service failure. Their article also addresses the issue of before emergency facility and after evacuation locating, while facilities face failure. The authors seek to establish a balance between the risk of evacuation and the operational cost of evacuation. To study a case in their article, were addressed three previous incidents in evacuation operations in the Mississippi region. The solution was also CPLEX, and the facilities reliability was one of the main points.

Qaderi et al. (2013) addressed the problem of locating-designing a dynamic capacity nonconstraints facilities network, taking into account budget constraints, and considering the healthcare facility for case study. It turns the issue into a dynamic problem by a multi-period case. The budget limitation also reveals itself in the reopening of a new healthcare facility or in a planning horizon. Two algorithms have been used to solve the proposed model includes greedy search algorithm and Fixed-and-Optimize algorithm based on refrigeration simulation and exact method. The performance of presented algorithms is investigated using numerical examples. An et al. (2017) focused on the reliability of the facility. In their article, referring to the loss caused by the facility failure, it is proposed to provide two reliable P-median locating models and the problem of fixed cost locating without reliable capacity. Both models deal with the facility failure, a supply layer, and a robustness of healthcare facilities with a limited budget. The Lagrange Relaxation (LR) Algorithm is also used to solve this problem. Lee et al. (2017) developed a P-center robust vertex model for locating emergency relief. In this model, the uncertainty for the time of transportation is taken into account, and this is shown by the specified intervals, rather than the probability distribution between the emergency relief centers and the 
affected districts. To solve the problem, a metaheuristic framework like refrigeration simulation is developed.

Finally, there are a few research focusing on the coverage issue:

Luo et al. (2017) used the data envelopment analysis approach by analyzing the location for the more effective integration of services in the healthcare sector. Their methodology considers the efficiency of healthcare providers based on multiple indexes. These efficiencies are then used to determine the location and allocation of resources of service providers. Mitropoulos et al. (2017) addressed a joint decision making on the location and distribution of emergency services. Their presented model combines an integer programming model with a hypercube model representing queuing and congestion phenomena. Due to the complexity of the problem, the genetic algorithm is used to solve it. The results of this model indicate minimization of response time and maximization of coverage. Touroe et al. (2017) presented a multi-objective optimization model for locating sustainable logistics facilities. They balanced considered economic services by environmental considerations based on a non-capacity locating model. Table 1 indicates the summary of literature review:

Table 1: literature review of research.

\begin{tabular}{|c|c|c|c|c|c|c|c|c|c|c|c|c|c|}
\hline \multirow[b]{2}{*}{$\begin{array}{l}\text { Ro } \\
\text { w }\end{array}$} & \multirow[b]{2}{*}{ Research } & \multicolumn{6}{|c|}{ single-objective } & \multicolumn{6}{|c|}{ multi-objective } \\
\hline & & 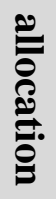 & 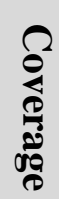 & 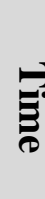 & 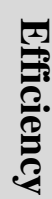 & ב & : & 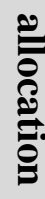 & 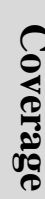 & ڤُ & 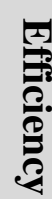 & & 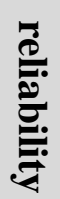 \\
\hline 1 & $\begin{array}{c}\text { Morali et al. } \\
\text { (2012) }\end{array}$ & - & - & - & - & & - & - & - & - & - & - & - \\
\hline 2 & $\begin{array}{c}\text { Sharif et al. } \\
\text { (2012) }\end{array}$ & - & $\square$ & - & - & - & - & - & - & - & - & & - \\
\hline 3 & $\begin{array}{l}\text { Vee et al. } \\
\text { (2012) }\end{array}$ & $\square$ & - & - & - & $\square$ & - & - & - & - & - & - & - \\
\hline 4 & $\begin{array}{c}\text { Pin and Mou } \\
\text { (2012) }\end{array}$ & - & - & - & - & $\square$ & - & - & - & - & - & - & - \\
\hline 5 & $\begin{array}{c}\text { Bremen et al. } \\
\text { (2013) }\end{array}$ & - & $\square$ & - & - & - & - & - & - & - & - & - & - \\
\hline
\end{tabular}




\begin{tabular}{|c|c|c|c|c|c|c|c|c|c|c|c|c|c|}
\hline 6 & $\begin{array}{c}\text { Ghaderi and } \\
\text { Jabalameli(20 } \\
13)\end{array}$ & - & $\square$ & - & & - & - & - & - & - & & - & - \\
\hline 7 & $\begin{array}{c}\text { Lee et al. } \\
(2017)\end{array}$ & - & $\square$ & - & - & - & - & - & - & - & - & - & - \\
\hline 8 & $\begin{array}{c}\text { Luo et al. } \\
(2017)\end{array}$ & - & - & $\square$ & - & - & - & - & - & - & - & - & - \\
\hline 9 & $\begin{array}{c}\text { Mitopoulos et } \\
\text { al. (2017) }\end{array}$ & - & - & - & - & - & - & - & $\square$ & - & $\square$ & - & - \\
\hline 10 & $\begin{array}{c}\text { Torou et al. } \\
\text { (2017) }\end{array}$ & - & - & $\square$ & - & - & - & - & - & - & - & - & - \\
\hline 11 & Present study & - & - & - & - & - & - & $\square$ & $\square$ & - & $\square$ & $\square$ & - \\
\hline
\end{tabular}

Regarding the literature review, the research innovations can be summarized as follows: addressing the available resources of the researcher and reviewing the work done, can find that a comprehensive study has not been carried out considering the level of efficiency and readiness to locate healthcare centers. It is worth taking into account the above items with more considerations, and this study seeks to address these items, then, a list of research innovations is as follows:

- Applying data envelopment analysis model and locating for healthcare and hospital centers

- Rehabiliting hospital services

- Providing accurate answers for the proposed model

- Providing a model for helping strategic health decisions

- Considering efficiency and readiness along with issues such as coverage and costs

\section{Capacity locating model and data envelopment analysis, taking into account the quality,} efficiency and relocation of healthcare facilities in order to improve the readiness level

This developmental model is based on the model Climberger et al., 2008, according to the efficiency index of hospital services for better use by clients. Parameters of the amount of capacity and distance values, as well as the allocation variable from the base model, and other parameters and variables are added to the base model by the author. This model assists the decision maker in adopting a macro policy decision and allows the relocation of existing services and capacities between hospitals to achieve lower costs while improving quality and efficiency (Climberg et al., 2008). The following assumptions are considered in this model: 
- Some services do not have the ability to relocation.

- There is no way to decide service relocation or add some services to some hospitals.

- There is ability to remove service from the hospitals under the decision.

- The hospital will provide the service with the same quality as previous in the event of an increase in capacity resulting from the addition of other hospital services.

- Following the relocation of hospital services to another hospital, the input resource of primary hospital provider will also be added to the input resource of second hospital with new services.

- Following the relocation of hospital services to another hospital, the outputs of primary hospital provider will also be added to the outputs of second hospital with new services.

- Costs will be included for service relocation.

The main question that this model deals with is the optimal allocation of hospital resources to best utilize the facilities in inappropriate financial and budgetary conditions. Identifying lowefficiency centers is another feature of this model.

Complex

Population centers and demand points

Hospitals complex

Hospital services complex

Hospital inputs complex

Hospital outputs complex

$$
\begin{aligned}
i & =1, \ldots, I \\
j & =1, \ldots, J \\
t & =1, \ldots, T \\
r & =1, \ldots, R \\
h & =1, \ldots, H
\end{aligned}
$$

A subset of $\mathrm{T}$, a set of available services in yhe hospital $\mathrm{j}$.

\section{Parameters}

Distance between $i$ and $j(i \in I, \mathrm{j} \in J)$

Demand of population center $i$ to service $t$

Operational cost of service $t$ in the hospital $j$

Input $r$ is for service $t$ in the hospital $j$

A penalty number in the first objective function for low degree of realization

if $d_{i j}<d_{\max }$, is 1 , otherwise 0

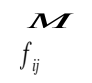

Indicating the treatment interested population in the healthcare $j$ from the hospital $i$, demonstrating the resources exploitation

Vital required volume in every open hospital or minimum needed volume to cure the population for justification of operation in the hospital 
Maximum allowance distance to allocate a population center to a hospital service

Service quality $t$ in the hospital $j$

A very small positive number

\section{Variables}

if service $i$ is provided in the hospital $j$, is 1 and otherwise 0

if population center $i$ is allocated to a serving hospital $t$ located in the center $j$, is 1 , otherwise 0 .

Lack variable of norm constraints

Input weight $r$ to service $t$ in the hospital $j$

$v_{j t r}$

$u_{j t h}$

$d e_{j t}$

$\boldsymbol{b}_{i j t}$

$$
\operatorname{Min} \sum_{i \in I} \sum_{j \in J} \sum_{t \in T} \frac{d_{i j}}{q_{j t}} b_{i j t}+M \cdot \sum_{j \in J} \sum_{t \in T} D_{j t}^{-}+\sum_{t \in T} \sum_{j \in J} o c_{j t} \sum_{j^{\prime} \in J} c a p_{j^{\prime} t} z_{j j t}+\sum_{t \in T} \sum_{j^{\prime} \in J} \sum_{j \in J} C M_{j^{\prime} t t} z_{j j^{\prime} t}
$$

Objective function (1) implies the minimization of the cost of distance-to-quality, the marginal cost of disregarding constraints of the exceeding critical capacity and the operational cost of service at the hospital, the operating costs, and the cost of service relocation between hospitals.

$$
\operatorname{Max} \sum_{j \in J} \sum_{t \in T}\left(1-d e_{j t}\right)
$$

Function (2) maximizes the service efficiency of hospitals for all demand points.

Subject to

$$
\sum_{j \in J} x_{i j t} \geq 1
$$

Constraint (3) satisfies demands.

$$
\sum_{j^{\prime}} z_{j j t} \leq M y_{j t} \quad j \in J, t \in T
$$

Constraint (4) from service $j$ will be provided in the hospital $j$, if there is service already in that hospital and is not transferred, or in the absence of that service in the hospital, is transferred from other hospital to that hospital.

$$
\begin{array}{ll}
y_{j t} \leq M \sum_{j^{\prime}} z_{j j t} & j \in J, t \in T \\
x_{i j t} \leq f_{i j t} y_{j t} & i \in I, j \in J, t \in T
\end{array}
$$


Constraints (5) and (6) specify the location and allocation decisions and ensure that each population center is located at the same distance referred to at least one hospital service provider.

$$
z_{j j t} \leq p_{j j t} \quad j^{\prime} \in J, j \in J, t \in T
$$

Constraint (7) indicates a service can be transferred from a hospital to another hospital if it can be transferred between origin and destination hospitals.

$$
\sum_{j} z_{j j t} \leq 1
$$

Constraint (8) demonstrates a service in a particular hospital can be transferred to one another hospital merely.

$$
\sum_{i \in I} c\left(d_{i j}\right) x_{i j t}+D_{j t}^{-} \geq c_{\min } y_{j t} \quad j \in J, t \in T
$$

Constraint (9) is the critical volume limit (capacity) related to the number of serviced patients, ensures that in each hospital, the minimum rate of curing for the population $D_{k}^{-}$is implemented with any facility operating at the healthcare center at point $k$. It should be remembered that norm constraint can be considered as a preferential constraint whose satisfaction is not limited but preferred. However, any violation of this constraint should be avoided as far as possible. In this model, the norm constraint has been used to prevent the non-coverage of residents in small communities, in other words, for some areas, they can be opened, even if they are insufficient and inadequate.

$$
\sum_{r \in R} v_{j t r} \sum_{j^{\prime}} I_{j t r} z_{j j t}=y_{j t} \quad \forall j \in J, \forall t \in s t(j)
$$

Constraint (10) indicates the inputs total weight $r$ from DMU as decision maker units is 1.

$$
\sum_{r \in R} v_{j t r} \sum_{j^{\prime}} I_{j t r} z_{j j t}=y_{j t} \quad \forall j \in J, \forall t \in s t(j)
$$

Constraint (11) exhibits the output weight is less than the corresponding inputs.

$$
\sum_{h \in H} u_{j t h} \sum_{j^{\prime}} O_{j t h} z_{j j t}+d e_{j t}=y_{j t} \quad \forall j \in J, \forall t \in s t(j)
$$

Constraint (12) introduces efficiency as the total weighted outputs $h$.

$$
\sum_{j \in J} b_{i j t}=w_{i t} \quad \forall i \in I, \forall t \in T
$$

Constraint (13) means the total number of visitors of one area to use of hospital services to different hospitals is equal with the demanded service in that area and ensures that the need for that service is satisfied. 


$$
\sum_{i} b_{i j t} \leq \sum_{j^{\prime}} \operatorname{cap}_{j^{\prime} t} z_{j^{\prime} t} \quad \forall j \in J, \forall t \in T
$$

Constraint (14) illustrates the total population allocated to hospital $j$ for a particular service should be less than the total capacity of the service in the hospitals.

$$
\begin{array}{ll}
u_{j t h} \geq \varepsilon y_{j t} & \forall j \in J, \forall t \in T, \forall h \in H \\
v_{j t r} \geq \varepsilon y_{j t} & \forall j \in J, \forall t \in T, \forall r \in R
\end{array}
$$

The demand constraints (15) and (16) indicates the nonnegative input and output weights.

$$
\begin{array}{ll}
b_{i j t} \leq M \cdot x_{i j t} & \forall i \in I, \forall j \in J, \forall t \in T \\
y_{j t} \leq \sum_{i \in I} b_{i j t} & \forall j \in J, \forall t \in T
\end{array}
$$

Constraints (17) and (18) show a population center use a hospital service center, if a proportion of the population of that area is allocated to the hospital service.

$$
\begin{array}{ll}
u_{j t h} \geq 0 & \forall i \in I, \forall j \in J, \forall t \in T \\
v_{j t r} \geq 0 & \forall i \in I, \forall j \in J, \forall t \in T \\
b_{i j t} \geq 0 & \forall i \in I, \forall j \in J, \forall t \in T \\
D_{j t}^{-} \geq 0 & j \in J, t \in T
\end{array}
$$

Constraints (19)-(22) are also positive variables.

$$
\begin{array}{ll}
z_{j^{\prime} j}^{t}=\{0,1\} & \forall j \in J, \forall j^{\prime} \in J, \forall t \in T \\
x_{i j t}=\{0,1\} & i \in I, j \in J, t \in T \\
y_{i j t}=\{0,1\} & i \in I, j \in J, t \in T
\end{array}
$$

Constraints (23)- (25) determine decision variables 1 and 0.

\section{Solution Method}

There are several methods for solving multi-objective problems, including the augmented $\varepsilon$-constraint method. In methods such as weighting method, the various weighting of objective functions yields different efficient solutions. However, in the augmented $\varepsilon$ constraint method, one of the objective functions is optimized and other objective functions are used in the constraint (Bemonie, 2017).

\subsection{The augmented epsilon constraint method 2 (Seyyed Sajjadi et al., 2014)}


In spite of the advantages of the epsilon constraint method rather than weighting method, two points need to be considered: the range of objective functions in an efficient set (generally Nadir values calculation) and ensuring the efficiency of the obtained solutions. The augmented epsilon constraint is a method for producing Pareto's optimal answers to math planning problems. As mentioned in the previous section, this method has advantages over the weighting method. The augmented epsilon constraint version called AUGMECON2, which is modification of its version 1 , has improved the objective function. This modification is due to the fact that if there were no optimal alternatives, it would apply like a Lexicographic optimization on the objective functions. The method steps are depicted in Fig. 1: 


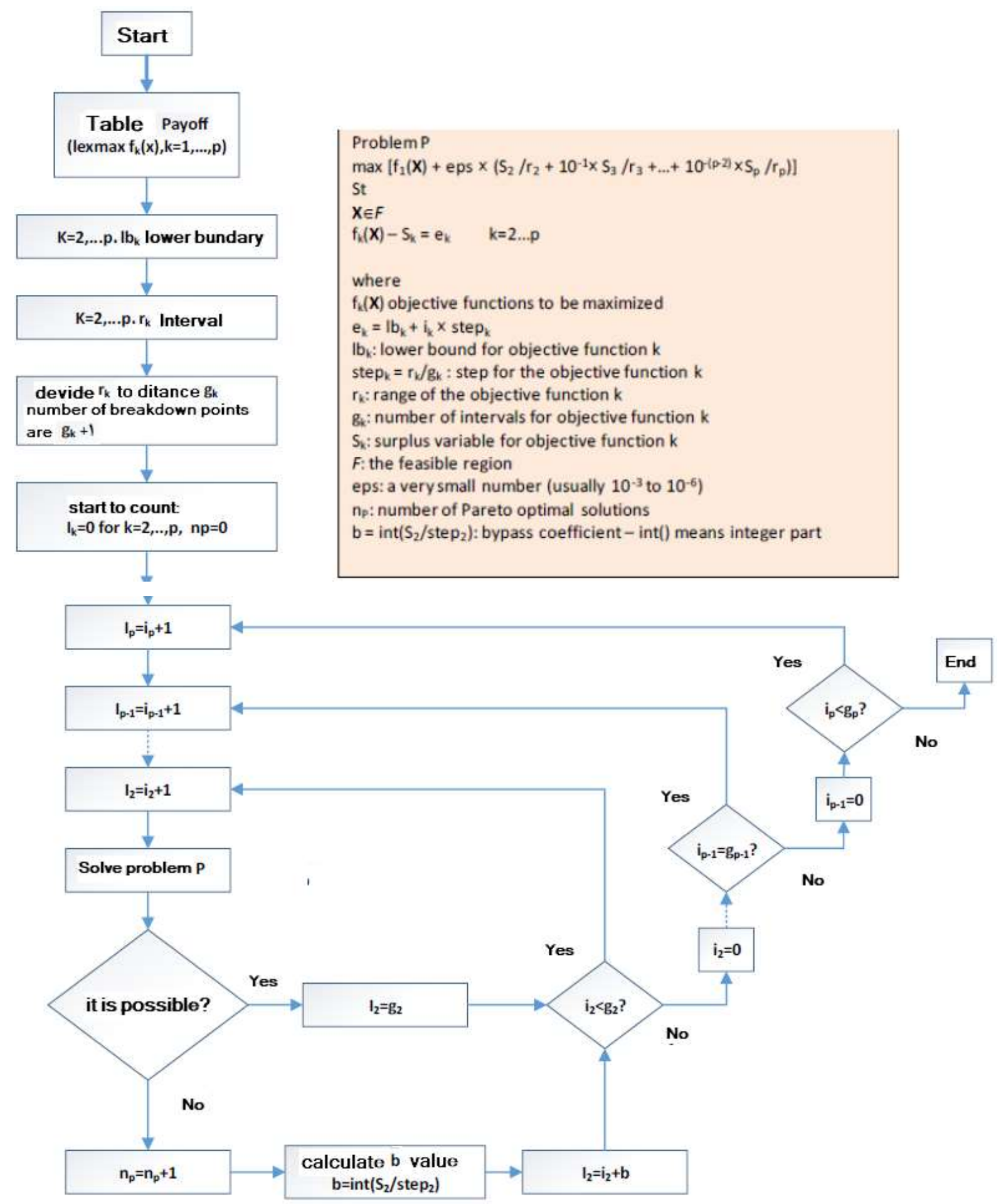

Fig. 1. Augmented epsilon constraint method. 


\section{Numerical examples}

In this section, using numerical examples and simulated information, the model is examined. Problem information is presented in Table 2. This table is information input of the problem for various examples to show that the proposed model is capable of solving for a variety of problem dimensions.

Table 2 - Numerical examples information.

\begin{tabular}{ccccccc}
\hline Row & $\begin{array}{c}\text { Number } \\
\text { of } \\
\text { hospitals }\end{array}$ & $\begin{array}{c}\text { Number } \\
\text { of } \\
\text { services }\end{array}$ & $\begin{array}{c}\text { Type of } \\
\text { city }\end{array}$ & $\begin{array}{c}\text { Number of } \\
\text { inputs }\end{array}$ & $\begin{array}{c}\text { Number of } \\
\text { outputs }\end{array}$ & $\begin{array}{c}\text { Solution } \\
\text { time } \\
\text { (second) }\end{array}$ \\
\hline 1 & 5 & 5 & small & 3 & 3 & $\mathbf{0 . 0 6 3}$ \\
2 & 15 & 5 & average & 3 & 3 & $\mathbf{0 . 1 4 5}$ \\
3 & 30 & 5 & big & 3 & 3 & $\mathbf{0 . 2 4 8}$ \\
4 & 60 & 5 & big & 3 & 3 & $\mathbf{0 . 6 8 2}$ \\
5 & 120 & 5 & metropolis & 3 & 3 & $\mathbf{5 . 1 8 8}$ \\
\hline
\end{tabular}

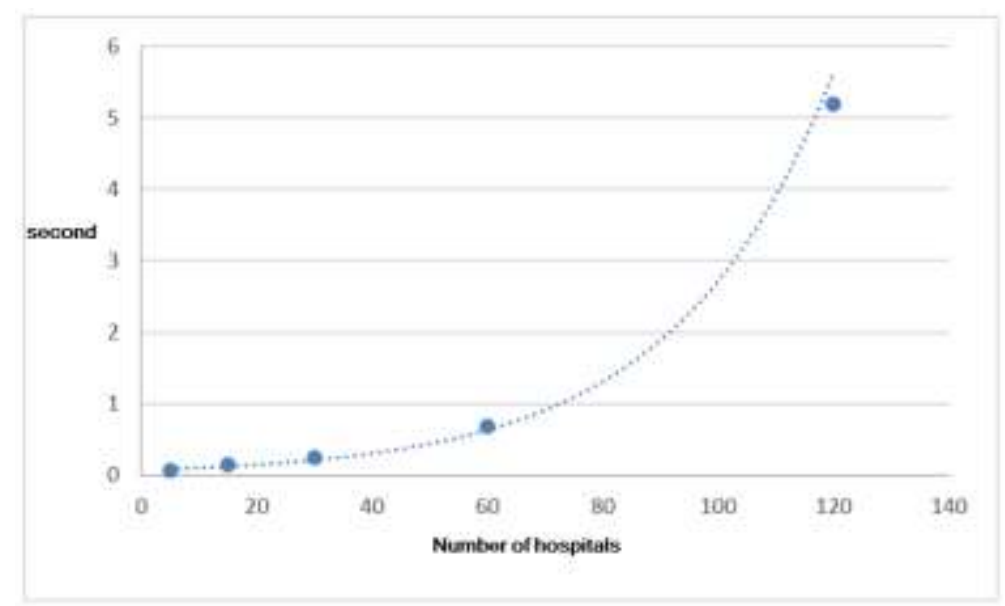

Fig. 2. Elapsed solution time of examples

Reviewing numerical examples and elapsed solution time by the GAMS software and the CPLEX solver indicate that it is possible to solve various urban dimensions with the proposed model at a very short time and exact response. Even for larger dimensions problem, the solution time is very small and there is no need to use methuristic and heuristic algorithms to solve it due to sufficient solution time using the exact solution approach. 


\section{Case study}

In this example, based on the information of hospitals in the Amol city in Iran, the proposed model is evaluated. The input information is taken from detailed geographic maps and interviews with experts. In Amol, there are 7 active hospitals with a variety of services includes two categories: private and public hospitals. The types of hospital services presented in Table 3. Amol city is divided into 4 sections according to geographical conditions. These sections, as indicated in Fig. 3, include Mahmoudabad, Noor, Imam Reza and Haraz. The seven hospitals of the city are also Imam Ali Hospital, Imam Reza Hospital, Peyman Private Hospital, Specialist North Private Hospital, Alborz Hospital, 17th Shahrivar Hospital and Ghaem Social Security Hospital. According to the information provided by Mazandaran University of Medical Sciences as responsible for the three main hospitals in Amol city (Imam Reza, Imam Ali and 17th September) and a review of more than $90 \%$ of the healthcare activities are performed in the Imam Reza, Imam Ali and 17th September hospitals, and social security hospitals, Aria and Peyman hospitals are limited activities hospitals. The North Hospital has been established since 2014 and is currently not using its full capacity, and use in the limited operations from the Aria Hospital. Therefore, according to available information from 2011, only the Peyman private hospital and three public hospitals of 17th September, Imam Ali and Imam Reza were selected as addressed hospitals, and other hospitals due to lack of the presence and semi-activating were excluded from the study.

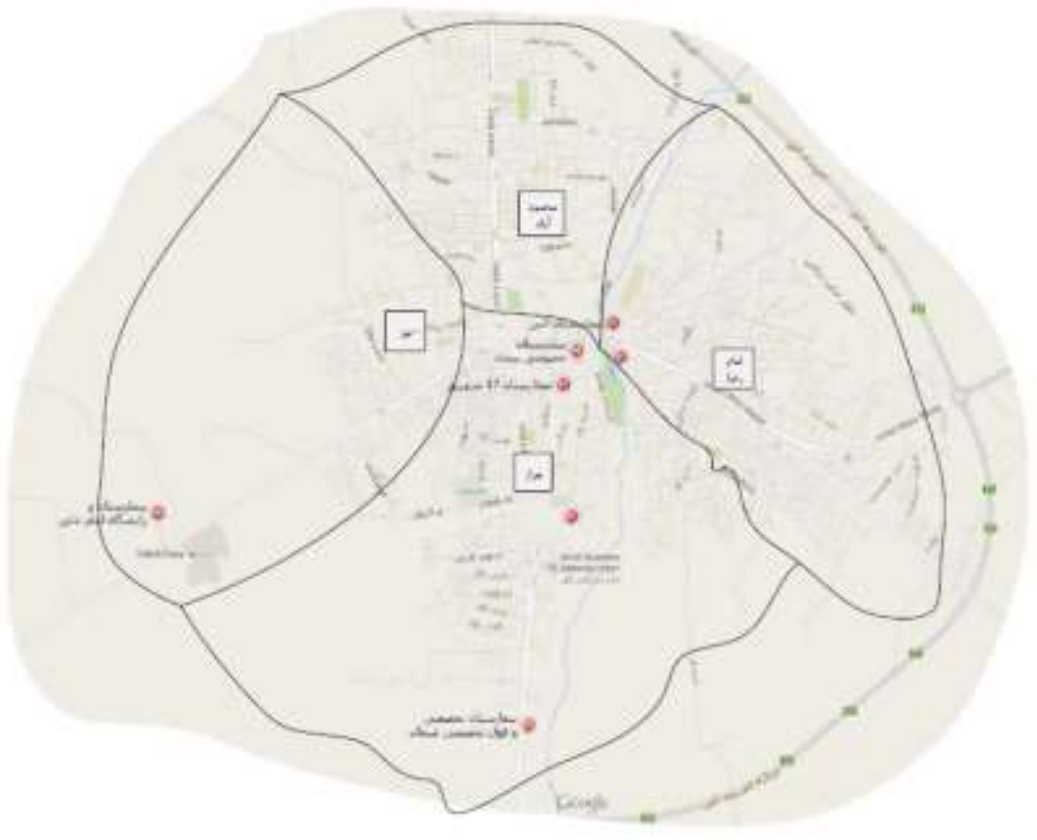

Fig. 3. Geographical division of Amol city (Source: behab.com) 
The services provided in hospitals are shown in Table 3.

Table 3 - Provided services in hospitals.

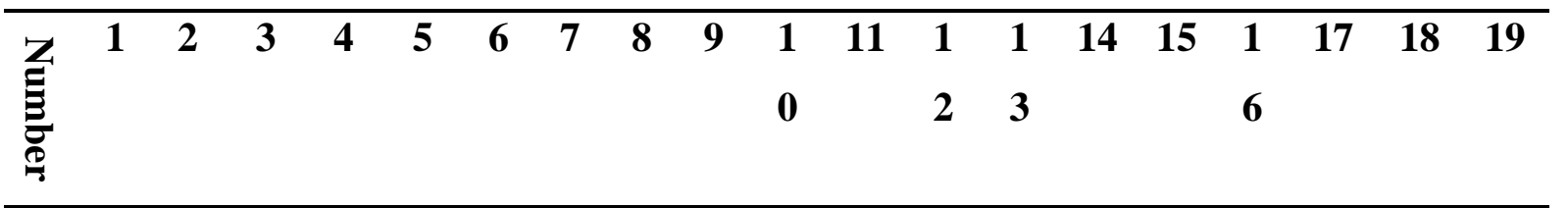

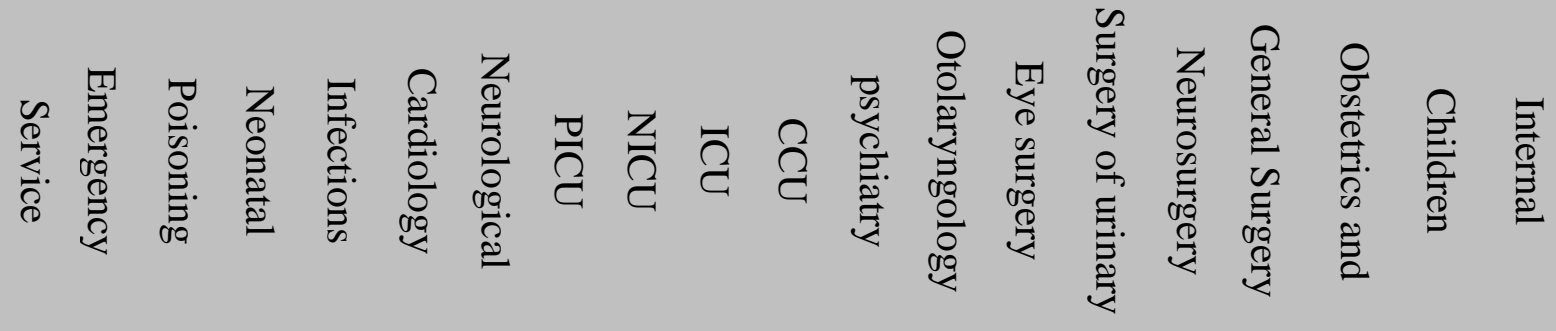

The distance between hospitals and population centers is shown in Table 4.

Table 4. Distances between hospitals and population urban centers $d_{i j}(\mathrm{~km})$.

\begin{tabular}{ccccc}
\hline $\begin{array}{c}\text { Hospital } \\
\text { Urban area }\end{array}$ & 17th Shahrivar & Imam Reza & Imam Ali & Peyman \\
\hline Noor & 4.8 & 7.3 & 2.9 & $\mathbf{5 . 8}$ \\
Mahmoud abad & 2.1 & 4.2 & 5.4 & $\mathbf{2 . 2}$ \\
Imam Reza & 2.5 & 1.5 & 6.6 & $\mathbf{1 . 9}$ \\
Haraz & 1 & 4.2 & 7 & $\mathbf{2 . 2}$ \\
\hline
\end{tabular}

\subsection{Problem solution with the proposed model}

As discussed in the explanation of the solution method, using the epsilon constraint method, the problem is solved based on the proposed model. In the following, Pareto points are estimated and analyzed. Finally, the sensitivity analysis will determine the model parameters. According to the flowchart presented in Fig. 1, one of the functions is considered as the remaining function, in which the cost function is selected as the main function, and the other transmitted function to the constraint section is the efficiency function. By calculating each individual function separately and obtaining the optimal values for each one, the results are obtained according to Table 5. 
Table 5: Separately solution results of each function.

\begin{tabular}{lcc}
\hline & $f_{1}$ & $f_{2}$ \\
\hline Min Cost $\mathrm{f}_{1}$ & 129655314590.3209 & $\mathbf{6 5 . 0 8 6}$ \\
& & \\
Max Efficiency f & 129655314590.3219 & $\mathbf{7 4 . 9 1 5}$ \\
\hline
\end{tabular}

The efficiency function interval is 9.829 based on the results. By breaking this interval to 11 distances, solution values are given for 10 breakpoints in accordance with Table 5:

Table 6 - Optimal results for breaking points in breakdown interval.

\begin{tabular}{cccc}
\hline Row & $f_{1}$ & $\mathbf{e}$ & $\mathbf{s}$ \\
\hline 1 & 129655314590.3209 & 65.086 & $\mathbf{9 . 2 3 3}$ \\
2 & 129655314590.3210 & 66.069 & $\mathbf{8 . 2 5 0}$ \\
3 & 129655314590.3211 & 67.052 & $\mathbf{7 . 2 6 7}$ \\
4 & 129655314590.3212 & 68.035 & $\mathbf{6 . 2 8 4}$ \\
5 & 129655314590.3214 & 69.018 & $\mathbf{5 . 3 0 1}$ \\
6 & 129655314590.3214 & 70.001 & $\mathbf{4 . 3 1 8}$ \\
7 & 129655314590.3215 & 70.984 & $\mathbf{3 . 3 3 5}$ \\
8 & 129655314590.3216 & 71.966 & $\mathbf{2 . 3 5 3}$ \\
9 & 129655314590.3218 & 72.949 & $\mathbf{1 . 3 7 0}$ \\
10 & 129655314590.3218 & 73.932 & $\mathbf{0 . 3 8 7}$ \\
11 & 129655314590.3219 & 74.915 & $\mathbf{0}$ \\
\hline
\end{tabular}

In Fig. 4, the Pareto optimal solution diagram plotted based on the decimal part of the cost function, which indicates the contrast between the two functions. And this means that an increase in the cost, an increase in efficiency will result while the model is needed to minimum cost and maximum efficiency. 


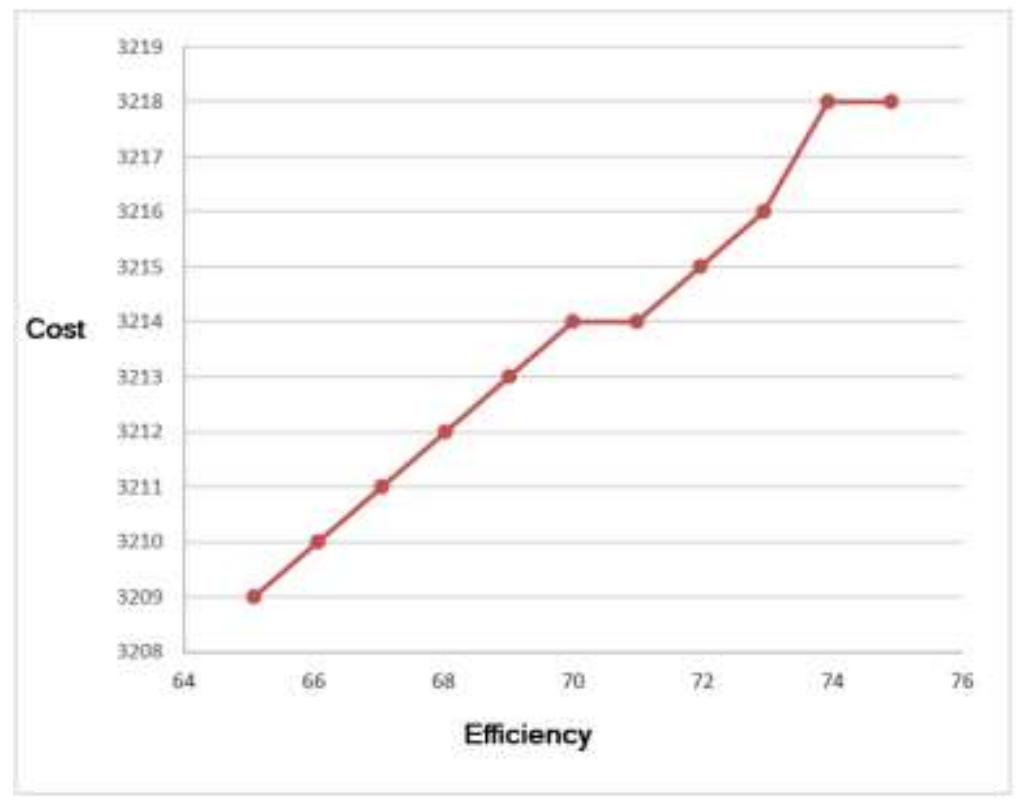

Fig. 4. Pareto optimal solution diagram.

To analyze the results of the model solution for the mentioned problem, the responses for rows 1 and 11 are examined. Responses are monitored for the number of allocated and open centers for providing services, the inefficiency of provided services, and the traveled distanceperson. It should be noted that the second objective function value is equal to the efficiency value. The inefficiency value is equal to one, minus the value of the second objective function value.

Table 7: The sum of the inefficiency values of provided services in percentage.

\begin{tabular}{lcc}
\hline & State 1 (minimum cost) & State 11 (maximum efficiency) \\
\hline Sum of inefficiency value & 10.914 & 1.085 \\
\hline
\end{tabular}

Table 8 clearly shows the difference between inefficiency in two optimal cost and optimal efficiency states. In state 1, cost savings have been attempted to keep open less efficiency centers, while in state 11, trying to maximize efficiency yields increasing cost. Budget constraints and existing conditions compel decision makers to adopt a decision between the two states. So in the first state, the total inefficiency is 10.914 percent and in the state 11 , the maximum efficiency is 1.085 percent.

Reviewing allocations in different areas is described in Table 8. 
Table 8: Results of state 1 and state 11 to compare the traveled distance and the number of users.

\begin{tabular}{|c|c|c|c|c|c|c|c|c|c|}
\hline \multicolumn{5}{|c|}{ State 11} & \multicolumn{5}{|c|}{ State 1} \\
\hline \multicolumn{3}{|c|}{ Hospitals } & \multicolumn{7}{|c|}{ Hospitals } \\
\hline $\begin{array}{l}\text { Pey } \\
\text { man }\end{array}$ & $\begin{array}{c}\text { 17th } \\
\text { Shahri } \\
\text { var }\end{array}$ & $\begin{array}{l}\text { Imam } \\
\text { Reza }\end{array}$ & $\begin{array}{l}\text { Im } \\
\text { am } \\
\text { Ali }\end{array}$ & & $\begin{array}{l}\text { Peym } \\
\text { an }\end{array}$ & $\begin{array}{c}\text { 17th } \\
\text { Shahriva } \\
\text { r }\end{array}$ & $\begin{array}{l}\text { Imam } \\
\text { Reza }\end{array}$ & $\begin{array}{c}\text { Ima } \\
\text { m } \\
\text { Ali }\end{array}$ & \\
\hline 2 & 10 & 7 & 5 & $\begin{array}{l}\text { Activ } \\
\text { e } \\
\text { servi } \\
\text { ces }\end{array}$ & 2 & 10 & 8 & 4 & $\begin{array}{c}\text { Active } \\
\text { services }\end{array}$ \\
\hline \multicolumn{3}{|c|}{ Distance } & \multicolumn{6}{|c|}{ Distance } & \\
\hline 5.8 & 4.8 & 7.3 & 2.9 & Noor & 5.8 & 4.8 & 7.3 & 2.9 & Noor \\
\hline 2.2 & 2.1 & 4.2 & 5.4 & $\begin{array}{l}\text { Mah } \\
\text { moud } \\
\text { abad }\end{array}$ & 2.2 & 2.1 & 4.2 & 5.4 & $\begin{array}{c}\text { Mahmouda } \\
\text { bad }\end{array}$ \\
\hline 1.9 & 2.1 & 1.5 & 6.6 & $\begin{array}{c}\text { Hara } \\
\text { z }\end{array}$ & 1.9 & 2.1 & 1.5 & 6.6 & Haraz \\
\hline 2.2 & 1 & 4.2 & 7 & $\begin{array}{c}\text { Ima } \\
\text { m } \\
\text { Reza }\end{array}$ & 2.2 & 1 & 4.2 & 7 & Imam Reza \\
\hline \multicolumn{4}{|c|}{ Number of users } & \multicolumn{6}{|c|}{ Number of users } \\
\hline 8 & 55 & 15 & 15 & Noor & 11 & 41 & 17 & 24 & Noor \\
\hline 3 & 66 & 18 & 19 & $\begin{array}{l}\text { Mah } \\
\text { moud } \\
\text { abad }\end{array}$ & 1 & 63 & 22 & 20 & $\begin{array}{c}\text { Mahmouda } \\
\text { bad }\end{array}$ \\
\hline 0 & 76 & 36 & 21 & $\begin{array}{c}\text { Hara } \\
\text { z }\end{array}$ & 0 & 69 & 44 & 20 & Haraz \\
\hline 0 & 71 & 26 & 33 & $\begin{array}{c}\text { Ima } \\
\text { m } \\
\text { Reza }\end{array}$ & 0 & 85 & 25 & 20 & Imam Reza \\
\hline \multicolumn{3}{|c|}{ User-km } & \multicolumn{7}{|c|}{ User-km } \\
\hline 9280 & 2640 & 766.5 & $\begin{array}{l}21 \\
7.5\end{array}$ & Noor & 1276 & 1968 & 992.8 & $\begin{array}{c}278 \\
.4\end{array}$ & Noor \\
\hline 13.2 & 1386 & 529.2 & 5.3 & $\begin{array}{l}\text { Mah } \\
\text { moud } \\
\text { abad }\end{array}$ & 4.4 & 1323 & 739 & 432 & $\begin{array}{c}\text { Mahmouda } \\
\text { bad }\end{array}$ \\
\hline 0 & 1596 & 378 & $\begin{array}{c}69 \\
3\end{array}$ & $\begin{array}{c}\text { Hara } \\
\text { z }\end{array}$ & 0 & 1449 & 528 & 528 & Haraz \\
\hline 0 & 710 & 764.4 & $\begin{array}{l}11 \\
55\end{array}$ & $\begin{array}{c}\text { Ima } \\
\text { m } \\
\text { Reza }\end{array}$ & 0 & 850 & 840 & 560 & Imam Reza \\
\hline & 114 & & & Total & & 1062 & & & Total \\
\hline
\end{tabular}


Reviewing the above results indicates a reduction in the traveled distance while reducing costs, while in the case of maximizing efficiency, an increase occurs in the number of persons / traveled $\mathrm{km}$ to use the service.

Table 8 - The result of redesign in two ststes (cost) 1 and (efficiency) 11

\begin{tabular}{|c|c|c|c|c|c|c|c|c|c|c|c|}
\hline $\begin{array}{c}\text { Efficien } \\
\text { cy }\end{array}$ & $\begin{array}{c}\text { Co } \\
\text { st }\end{array}$ & $j^{\prime} j t$ & $\begin{array}{c}\text { Efficien } \\
\text { cy }\end{array}$ & $\begin{array}{c}\text { Co } \\
\text { st }\end{array}$ & $j^{\prime} j t$ & $\begin{array}{c}\text { Efficien } \\
\text { cy }\end{array}$ & $\begin{array}{l}\text { Co } \\
\text { st }\end{array}$ & $j^{\prime} j t$ & $\begin{array}{c}\text { Efficien } \\
\text { cy }\end{array}$ & $\begin{array}{c}\text { Cos } \\
\mathrm{t}\end{array}$ & $j^{\prime} j t$ \\
\hline 1 & 1 & $\begin{array}{c}4.4 . \\
3\end{array}$ & 1 & 1 & $\begin{array}{c}3.1 . \\
4\end{array}$ & 1 & 1 & $\begin{array}{c}2.1 . \\
4\end{array}$ & 1 & 1 & $\begin{array}{c}1.1 .1 \\
2\end{array}$ \\
\hline \multirow[t]{19}{*}{1} & 1 & $\begin{array}{c}4.4 . \\
6\end{array}$ & 1 & . & $\begin{array}{c}3.1 . \\
8\end{array}$ & . & . & $\begin{array}{c}2.1 . \\
5\end{array}$ & 1 & 1 & $\begin{array}{c}1.1 .1 \\
3\end{array}$ \\
\hline & & & 1 & . & $\begin{array}{c}3.1 . \\
9\end{array}$ & 1 & . & $\begin{array}{c}2.1 . \\
14\end{array}$ & 1 & 1 & $\begin{array}{c}1.1 .1 \\
8\end{array}$ \\
\hline & & & . & . & $\begin{array}{c}3.1 . \\
10\end{array}$ & . & . & $\begin{array}{c}2.1 . \\
15\end{array}$ & 1 & 1 & 1.3.1 \\
\hline & & & . & 1 & $\begin{array}{c}3.2 . \\
8\end{array}$ & 1 & . & $\begin{array}{c}2.1 . \\
16\end{array}$ & 1 & 1 & 1.3.2 \\
\hline & & & . & 1 & $\begin{array}{c}3.2 . \\
9\end{array}$ & 1 & . & $\begin{array}{c}2.1 . \\
17\end{array}$ & 1 & 1 & 1.3.3 \\
\hline & & & 1 & 1 & $\begin{array}{c}3.3 . \\
3\end{array}$ & 1 & . & $\begin{array}{c}2.1 . \\
19\end{array}$ & & & \\
\hline & & & 1 & 1 & $\begin{array}{c}3.3 . \\
5\end{array}$ & 1 & 1 & $\begin{array}{c}2.2 . \\
6\end{array}$ & & & \\
\hline & & & 1 & 1 & $\begin{array}{c}3.3 . \\
6\end{array}$ & . & 1 & $\begin{array}{c}2.2 . \\
8\end{array}$ & & & \\
\hline & & & 1 & 1 & $\begin{array}{c}3.3 . \\
7\end{array}$ & . & 1 & $\begin{array}{c}2.2 . \\
9\end{array}$ & & & \\
\hline & & & 1 & 1 & $\begin{array}{c}3.3 . \\
12\end{array}$ & 1 & 1 & $\begin{array}{c}2.2 . \\
10\end{array}$ & & & \\
\hline & & & . & 1 & $\begin{array}{c}3.3 . \\
16\end{array}$ & 1 & 1 & $\begin{array}{c}2.2 . \\
11\end{array}$ & & & \\
\hline & & & . & 1 & $\begin{array}{c}3.3 . \\
17\end{array}$ & 1 & 1 & $\begin{array}{c}2.2 . \\
12\end{array}$ & & & \\
\hline & & & . & . & $\begin{array}{c}3.3 . \\
18\end{array}$ & . & 1 & $\begin{array}{r}2.2 . \\
14\end{array}$ & & & \\
\hline & & & & 1 & $\begin{array}{c}3.3 . \\
19\end{array}$ & 1 & 1 & $\begin{array}{c}2.2 . \\
15\end{array}$ & & & \\
\hline & & & & & & 1 & 1 & $\begin{array}{c}2.3 . \\
1\end{array}$ & & & \\
\hline & & & & & & 1 & 1 & $\begin{array}{c}2.3 . \\
2\end{array}$ & & & \\
\hline & & & & & & . & 1 & $\begin{array}{c}2.3 . \\
16\end{array}$ & & & \\
\hline & & & & & & . & 1 & $\begin{array}{c}2.3 . \\
17\end{array}$ & & & \\
\hline & & & & & & . & 1 & $\begin{array}{c}2.3 . \\
19\end{array}$ & & & \\
\hline
\end{tabular}


The result of the redesigning in the allocations and provided services in various hospitals is presented in Table 8. For example, by verifying Service No. 4 (General Surgery) at Hospital No. 1 (Imam Ali), this service was not initially active, but by redesigning and relocating, two other hospitals allocated the their capacities for conducting all general surgery in this hospital. An interesting point in both states 1 and 11 can be found for Hospital 2 (Imam Reza), which attempts to reduce the cost of redesigning the service capacity 16 (infectious disease) allocates this hospital to the hospital 3 (17th September), but to increase efficiency transfers this service to Hospital 1 (Imam Ali).

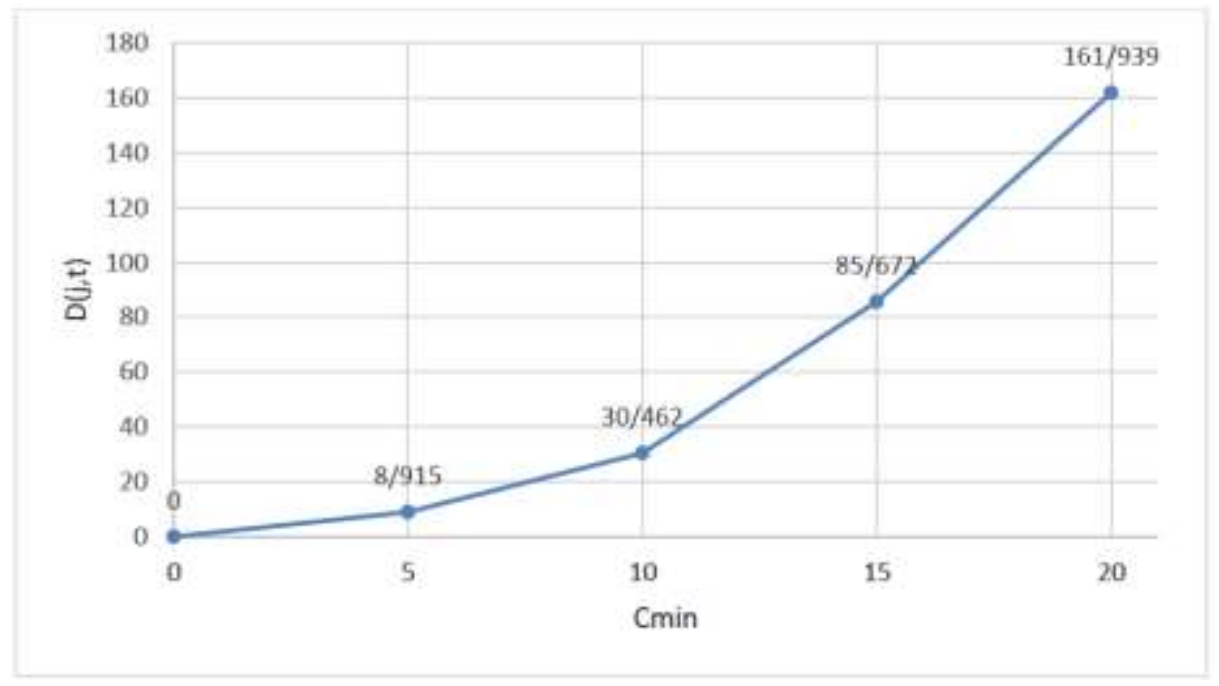

Fig. 5. The sensitivity of $\mathrm{D}(\mathrm{j}, \mathrm{t})$ to the $\mathrm{C}_{\min }$ values.

Fig. 5 indicates with increasing $\mathrm{c}_{\min }$, model tolerates more penalty, so that people who need a particular service and without alternative can use it. Indeed, the model itself exhibits the flexibility to deal with such lacks, and prevents from demands incertituding or forcing applicants to bear a higher cost. The parameter $c_{\min }$ represents the minimum number of applicants for a service to re-open it in the hospital. However, due to the fact that sometimes only demand for services is low and, on the other hand, there is no replacement for that service, or if it is found, the cost is much higher, so is taken into account the lack variable, such as $D_{j t}^{-}$

As it is known, increasing system costs will increase the efficiency and increase the readiness of the centers. This means that an increase in cost, will lead to an increase in efficiency, if the model seeks to reduce costs and increase efficiency. The proposed model allows for a redesign of services for services that are not used efficiently in hospital centers and in contrast to other centers at the highest performance levels. . The redesign is based on the fact 
that it is possible to relocation in the considered hospital, and if it is physically possible, the service capacity will be transferred from the inefficient hospital to the efficient hospital. In fact, the aim of the proposed model is to provide an approach to optimal locating of facilities and, consequently, to reduce investment and operational costs. In addition, it is assumed that higher quality leads to more customer or applicants for a service center. This issue is included in the models presented in this study by considering different factors that indicate the referral rates for a hospital and the first proposed model follows to minimize the cost of distance to quality, along with the underwork cost and exceeding critical capacity also are included.

This will lead to more available facilities to the high performance hospital, and to see applicants' satisfaction in this regard. The model can be used at various levels, such as, inside of city and between cities even in larger dimensions, such as between provinces and countries. In this model, it is assumed that in the event of the transfer, all capacity of the service can transfer to another hospital.

\section{Conclusion}

The effect of services and efficiency is locating and allocating services and reexamining hospital capacities. By measuring the efficiency and readiness indexes through data envelopment analysis models and ranking the provided services, a more precise decision can be made and is considered a review of the applied policies. In this paper, research gaps are identified and considering demands for the health system, a model is presented.

The proposed model is based on the model Kelimberg et al., 2008, which allows for services that are not used efficiently in hospital centers and in contrast to other centers at the highest efficiency levels, redesign services are conducted. The redesign is based on the fact that at first there is a possible transfer in the considered hospital, and if physically possible, the service capacity will be transferred from the inefficient hospital to the efficient hospital. This will lead to more available facilities to the high performance hospital, and to see applicants' satisfaction in this regard. The model can be used at various levels, such as inside of city, between cities and even in larger dimensions, such as between provinces and countries. In this model, it is assumed that in the event of the transfer, all the capacity of the service can transfer to another hospital.

In fact, the aim of the proposed model is to provide an approach to optimal locating of facilities and, consequently, to reduce investment and operational costs. In addition, it is 
assumed that higher quality leads to more customer or applicants for a service center. This issue is included in the models presented in this study by considering different factors that indicate the referral rates for a hospital and the first proposed model follows to minimize the cost of distance to quality, along with the underwork cost and exceeding critical capacity also are included.

The proposed model has shown that in large dimensions, even as the city of Tehran, it has the most precise response at the fastest time and there is no need to use the meta-heuristic algorithms to solve it. The model is solved using the augmented $\varepsilon$-constraint method, which is a suitable method for multi-objective models. The carried out analysis on the actual sample for Amol city hospitals indicates that decision-makers' attention to cost or performance will lead to different decisions. For future studies, suggestions are presented as follows:

- Providing a model to allow construction of new centers

- Considering the reopening of new services for existing hospitals

- Studying on uncertainty data.

\section{References}

Akkihal, A. (2006). Inventory pre-positioning for humanitarian logistics. MS thesis, Massachusetts Institute of Technology.

Alireza Tajbakhsh, A. (2019). A facility location problem for sustainability-conscious power generation decision makers, Journal of Environmental Management Volume 230, 15 January, Pages 319-334

Altay, N., and Green, W. G. (2006). OR/MS research in disaster operations management. European Journal of Operational Research, 175(1), 475-493.

Berman O., Krass D., and M. B. C. Menezes (2013). Location and reliability problems on a line: Impact of objectives and correlated failures on optimal location patterns. Omega, vol. 41, no. 4, 766-779.

Boonmee C,; Arimura M.; Asada T. (2017). Facility location optimization model for emergency humanitarian logistics. International Journal of Disaster Risk Reduction; 24: 485-498.

C.-C. Lu and J.-B. Sheu, (2017). "Robust vertex p-center model for locating urgent relief distribution centers," Comput. Oper. Res., vol. 40, no. 8, pp. 2128-2137, Aug.

Ghaderi A. and Jabalameli, M. M. S. (2013). Modeling the budget-constrained dynamic uncapacitated facility location-network design problem and solving it via two efficient heuristics: A case study of health care. Math. Comput. Model., vol. 57, no. 3-4, 382-400.

H. Toro-díaz, M. E. Mayorga, S. Chanta, and L. a. Mclay (2017). "Joint location and dispatching decisions for Emergency Medical Services," Comput. Ind. Eng., vol. 64, no. 4, pp. 917-928, Apr.

Hui Li, Jingxiao Zhang,Chao Wang,Yujie Wang,Vaughan Coffey (2018). An evaluation of the impact of environmental regulation on the efficiency of technology innovation using the combined DEA model: A case study of Xi'an, China, Sustainable Cities and Society, Volume 42, October 2018, Pages 355-369

Hong, X. Lejeune, MA. and Noyan, N. (2015). "Stochastic network design for disaster preparedness. IIE Transactions, 47(4), 329-357. 
Klimberg R. and Ratick,S. (2008).Modeling data envelopment analysis (DEA) efficient location/allocation decisions. Comput. Oper. Res.

Murali,P. Ordóñez,F. and Dessouky, M. M. M. (2012). Facility location under demand uncertainty: Response to a large-scale bio-terror attack. Socioecon. Plann. Sci., vol. 46, no. $1,78-87$.

Nagurney, A. Alvarez Flores, a Soylu. C. (2016). A Generalized Nash Equilibrium network model for post-disaster humanitarian relief, Transportation research part E: logistics and transportation review, VOL95, 1-18 https://behrah.com/map.php?id=462

Nedjati, A, Izbirak, G, and Arkat, J. (2017). Bi-objective covering tour location routing problem with replenishment at intermediate depots: Formulation and Meta-heuristics. Computers \& Industrial Engineering, 110, 191-206.

P. Mitropoulos, I. Mitropoulos, and I. Giannikos (2017). "Computers \& Operations Research Combining DEA with location analysis for the effective consolidation of services in the health sector," Comput. Oper. Res., vol. 40, no. 9, pp. 2241-2250.

Q. Li, B. Zeng, and A. Savachkin (2017). "Reliable facility location design under disruptions," Comput. Oper. Res., vol. 40, no. 4, pp. 901-909, Apr.

Seyed Jafar Sadjad,iMehdi Heidari,Amin Alinezhad Esboei,Augmented (2014). S-constraint method in multiobjective staff scheduling problem: a case study, The International Journal of Advanced Manufacturing Technology Volume 70, Issue 5-8, pp 1505-1514

Schiffer, M, Walther, G. (2017). The electric location routing problem with time windows and partial recharging, European Journal of Operational Research. 260(3) · January 2017. DOI - 10.1016/j.ejor.2017.01.011

YinP. and Mu,L.(2012). Modular capacitated maximal covering location problem for the optimal siting of emergency vehicles. Appl. Geogr., vol. 34, 247-254.

Zhao Xin-gang,We iZhen, (2019). The technical efficiency of China's wind power list enterprises: An estimation based on DEA method and micro-data, Renewable Energy, Volume 133, April Pages 470-479

Wei,L. Li, W. Li,K. Liu,H. and Cheng, L.(2012). Decision Support for Urban Shelter Locations Based on Covering Model. Procedia Eng., vol. 43, pp. 59-64. 